Full length article

\title{
Australia's leading public health body delays action on the revision of the public health goal for blood lead exposures
}

\author{
Mark Patrick Taylor $^{\mathrm{a}, *}$, Chris Winder ${ }^{\mathrm{b}}$, Bruce P. Lanphear ${ }^{\mathrm{c}}$ \\ a Environmental Science, Department of Environment and Geography, Faculty of Science, Macquarie University, Sydney, NSW 2109, Australia \\ b Safety and Environmental Management, Australian Catholic University, North Sydney, NSW 2060, Australia \\ c BC Children's Hospital, Faculty of Health Sciences, Simon Fraser University, Vancouver, British Columbia V5A 1S6, Canada
}

\section{A R T I C L E I N F O}

\section{Article history:}

Received 15 January 2014

Accepted 14 April 2014

Available online 10 June 2014

\section{Keywords:}

Blood lead

Children

Exposure

Lead

Policy

\begin{abstract}
A B S T R A C T
Globally, childhood blood lead levels have fallen precipitously in developed countries since the 1970s following action by international bodies such as the WHO and Food and Agricultural Organization (FAO) of the United Nations. These reductions have been affected by the activities of national agencies such as the US EPA and US Centers for Disease Control and Prevention in the establishment of air lead and blood lead standards, the introduction of legislation to remove lead from petrol, paint and consumer products and tighter restrictions on lead emissions. The outcome of recent major international reviews of research into the effects of low-level lead exposures (e.g. by WHO, USA health and environmental agencies, German and Canadian health bodies) has resulted in recommendations to reduce and eliminate lead exposures. By contrast, Australian policy responses to the incontrovertible evidence that adverse neurocognitive and behavioural effects that occur at levels well below the current national goal of $10 \mu \mathrm{g} / \mathrm{dL}$ have stalled. The delayed response by Australia occurs at a time when blood lead levels in two of Australia's three primary lead mining and smelting cities: Port Pirie, South Australia and Broken Hill, New South Wales, are rising. In the third city, Mount Isa, Queensland, there is still no systematic, annual testing of childhood blood lead values. This is despite the fact that Mount Isa has the highest lead (and other toxic metals such as cadmium and arsenic) emissions to the environment (120 tonnes of lead in 2011/12) from any single point source in Australia. It is clear that both state and national policy approaches to the ongoing risks of lead exposure need to be revised urgently and in line with contemporary international standards. Recommended changes should include a new lower blood lead intervention level of no more than $5 \mu \mathrm{g} / \mathrm{dL}$, with a national goal for all children under 5 years of age to have a blood lead level of below $1 \mu \mathrm{g} / \mathrm{dL}$ by 2020. In order to achieve any new lower exposure goals other relevant lead standards including air, dust, soil and water must also be revised downwards.
\end{abstract}

(c) 2014 Elsevier Ltd. All rights reserved.

\section{Introduction}

The measurement of lead in the remains of pre-industrial humans has shown that the natural levels of lead were $0.016 \mu \mathrm{g} / \mathrm{dL}$ (Flegal and Smith, 1992), 625 times less than the current recommended public health goal in Australia (10 $\mu \mathrm{g} / \mathrm{dL})$. In the 1960s, health agencies in Europe and the USA set, and then lowered (as more evidence became available) a blood lead "level of concern" from $60 \mu \mathrm{g} / \mathrm{dL}$ to $40 \mu \mathrm{g} / \mathrm{dL}$ in 1971 , to $30 \mu \mathrm{g} / \mathrm{dL}$ in 1985 , and lastly, to $10 \mu \mathrm{g} / \mathrm{dL}$ in 1991 (see Fig. 1). The level of concern was used by pediatricians and other health professionals to establish priorities and manage a lead poisoned child. In 2009, Germany lowered the reference value for children's (aged 3-14 years) blood lead level to $3.5 \mu \mathrm{g} / \mathrm{dL}$ (Schultz et al., 2011). In 2012, the US CDC

\footnotetext{
* Corresponding author.

E-mail address: mark.taylor@mq.edu.au (M.P. Taylor).
}

eliminated the "level of concern" set at $10 \mu \mathrm{g} / \mathrm{dL}$ and established $5 \mu \mathrm{g} /$ $\mathrm{dL}$ as the intervention (reference) level for individual children (CDC, 2012). Following substantive reviews of the research evidence, several other major international health bodies have also issued similar recommendations that lead exposure, particularly in children, must be reduced or eliminated (FAO/WHO, 2010; Health Canada, 2013; US NTP, 2012; WHO, 2010).

In 1993, Australia's current blood lead goal of $10 \mu \mathrm{g} / \mathrm{dL}$ was established after being revised downwards from the 1983 level of $25 \mu \mathrm{g} / \mathrm{dL}$. The new lower standard mirrored the blood lead level established by the US Centers for Disease Control (CDC) in 1991 (Fig. 1). The figure of $10 \mu \mathrm{g} / \mathrm{dL}$ was reaffirmed by the National Health and Medical Research Council (NHMRC) after a review in 2009 (NHMRC, 2009), which concluded that "The nature of the 'doseresponse' relationship between lead exposure and children's intellectual abilities and behaviour is also contentious." Importantly however, the NHMRC (2009) also noted in their information paper that "No threshold 


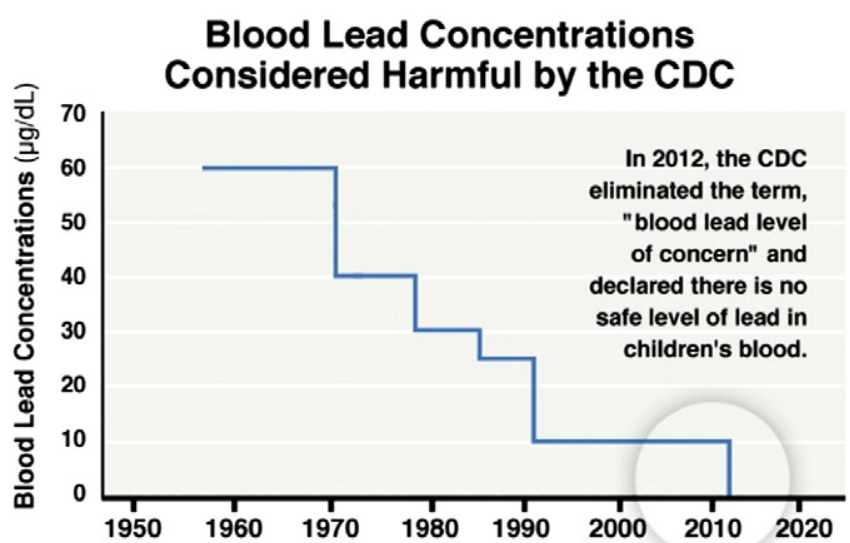

Fig. 1. Changes to the blood lead 'level of concern' over the last 50 years as determined by the US Centers for Disease Control and Prevention (reproduced with permission of the Canadian Environmental Health Atlas, 2014).

of lead exposure below which any exposure might be considered 'safe' in respect of cognitive abilities has ever been identified." The NHMRC is currently examining the existing blood lead goal for Australia and was meant to report its findings in late 2013/early 2014 (NHMRC, 2014), but the outcomes of the review have been delayed.

To date, the majority of research on the neurocognitive and behavioural effects of lead exposure has been conducted in the USA, with very few studies from Australia examining the impacts and long-term outcomes in terms of school performances or criminality (e.g. Mielke and Zahran, 2012). The majority of Australian published research was conducted in the 1990s and was based on Port Pirie children, who had higher lead levels from smelter emissions than are typically found today either there or elsewhere. However, Rachel Earl's, 2011 University of Adelaide PhD study investigated the effects of low-level lead exposure on 106 children (whose arithmetic mean blood lead concentration was $4.97 \mu \mathrm{g} / \mathrm{dL}$ ) from Port Pirie and Broken Hill (Earl, 2011). This study, which drew the same conclusions as previous international studies, showed that there is no apparent threshold for the toxic effects of lead (Lanphear et al., 2005). Importantly, the study's findings re-affirmed that the lowest levels of lead exposure are associated with proportionately greater impact on children's cognition relative to higher levels of exposure.
In short, this means that prevention of any lead exposure must be a key goal of any public policy; the de facto goal of only aiming to keep children's blood lead below $10 \mu \mathrm{g} / \mathrm{dL}$ in Port Pirie (Thumbs up for Low Levels, 2013); Mount Isa (Living with Lead, 2013); and Broken Hill (Lesjak, 2012) is obsolete and will inevitably fail to protect children from the toxic effects of lead.

\section{The effects and absorption of lead exposure are non-trivial and are lifelong}

The United States Environmental Protection Agency (US EPA, 2013) Integrated Science Assessment for Lead concluded that the weight of evidence shows adverse cognitive function effects of lead exposure on populations of children down to $2 \mu \mathrm{g} / \mathrm{dL}$. The effects of exposure may be irreversible and persist into adulthood (US EPA, 2013; US NTP, 2012).

Lead exposure is associated with delayed pubertal onset and adverse reproductive and developmental effects in young adults who have mean blood levels less than or equal to $5 \mu \mathrm{g} / \mathrm{dL}$ (US EPA, 2013; US NTP, 2012). Adults are not immune to low-level toxicity; causal relationships having been shown to exist between low-lead exposures (below $10 \mu \mathrm{g} / \mathrm{dL}$ ) and adverse cardiovascular effects (e.g. increased blood pressure, hypertension, coronary disease) (e.g. Menke et al., 2006; Schober et al., 2006; US EPA, 2013). In addition, the US EPA (2013) concluded that there was a likely causal relationship between lead exposure and reduced kidney function, all of which are considered to reduce lifespan and quality. The US EPA (2013) concluded that the current toxicological evidence from studies examining the effects of elevated blood lead levels (range 5-43 $\mu \mathrm{g} / \mathrm{dL}$ ) provided strong evidence that exposure reduces semen quality and that it may also affect some aspects of female reproductive function.

In 2012, the United States Centers for Disease Control (CDC) recommended that the term "level of concern" be discarded and that the blood lead level of $10 \mu \mathrm{g} / \mathrm{dL}$ as a child health goal be revised. Consequently, the $\mathrm{CDC}$ is now using a reference value of $5 \mu \mathrm{g} / \mathrm{dL}$ to identify children who have been exposed to lead and require case management (CDC, 2012). If Australia adopted a reference value of $5 \mu \mathrm{g} / \mathrm{dL}, 50 \%$ or more of the children under 5 years of age in Broken Hill, Mount Isa and Port Pirie would need greater protection and intervention unless lead emissions are drastically reduced.

Although national blood lead values are falling in major cities and mining towns in Australia (Fig. 2), the benign neglect of lead exposure is evident in Medicare statistics that show 107,810 blood lead tests were conducted on all Australians in the last decade (July 2003-August

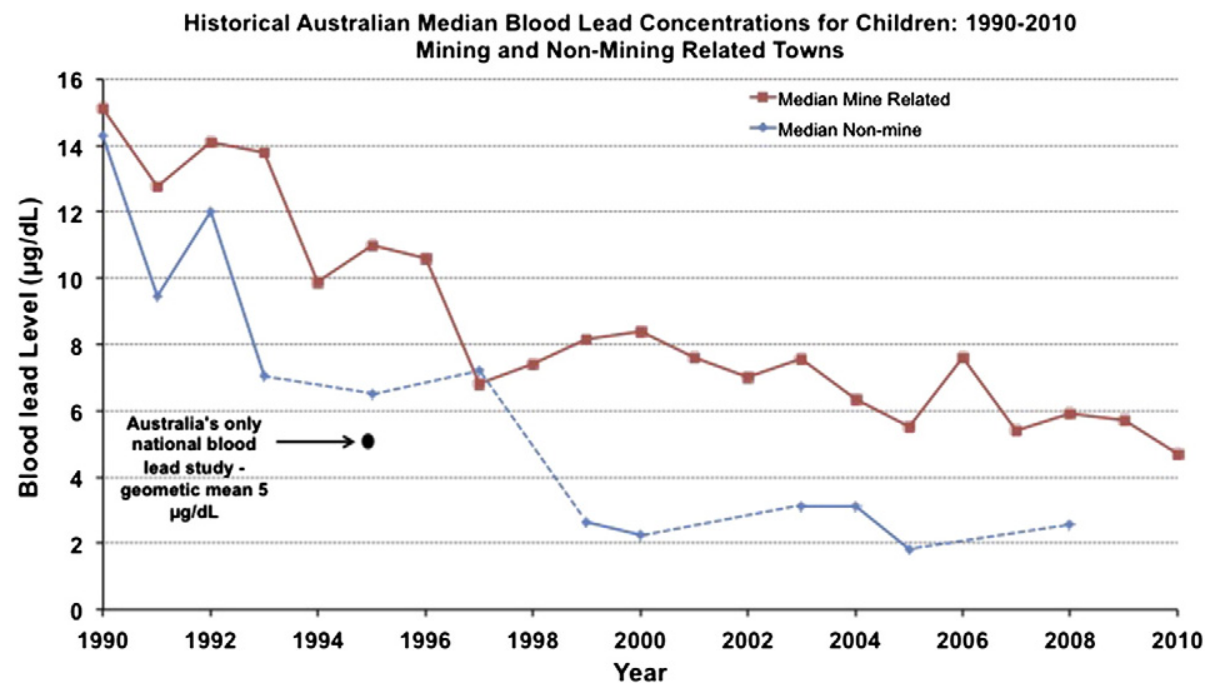

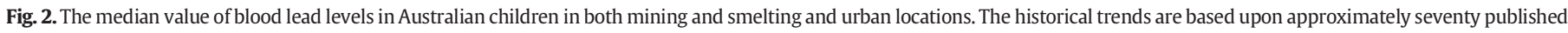

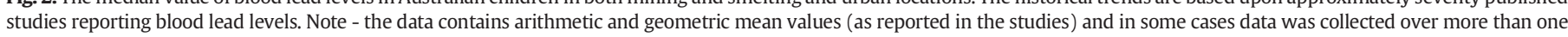

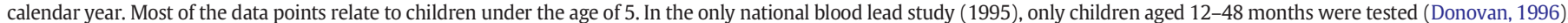


2013) (Medicare Australia Statistics, 2014). It is an unfortunate and a significant lost opportunity that the results from these tests are not captured, stored and analyzed by the Australian Institute of Health and Welfare (AIHW), despite that one of their 'primary roles is to collect, analyze and report information drawn from health services, community services and housing assistance services' (AIHW, 2014). Indeed, part of its statutory work as listed under the Australian Institute of Health and Welfare Act 1987, the functions of the Institute include (inter alia) at Section 5 (1)(f) of the Act: 'to conduct and promote research into the health of the people of Australia and their health services' (Australian Government ComLaw, 2014). In the absence of collation and analysis of such raw data (we understand that the AIHW does not perform this role at present, though we have suggested that they might consider it), or a regular national blood lead survey of all ages (as have been carried out regularly in the USA since 1976), we used USA population lead exposure data to estimate that approximately 100,000 Australian children under five years of age may be exposed to blood levels above $5 \mu \mathrm{g} / \mathrm{dL}$, which are likely to cause adverse health effects (Taylor et al., 2012). In the most recent study of blood lead of Australian children in a large urban city (Sydney), Gulson et al. (2008) reported that $7.5 \%(8 / 107)$ of their cohort of children presented with a blood lead $>10 \mu \mathrm{g} / \mathrm{dL}$. This is the last reference value from an urban environment and according to Gulson (2014), p. 372 "the randomness of our sampling in Sydney is sufficient to obtain a reliable estimate of $\mathrm{PbB}$ distributions from an urban environment". Therefore by deduction, this study's data suggests that around 100,000 Australian children (ABS, 2013) aged 0-4 years will experience an elevated blood lead above $10 \mu \mathrm{g} / \mathrm{dL}$. The point being is that the evidence suggests that the environmental lead problem has not 'gone away'. It would be more accurate to state that its true effect on the community is largely silent because of the dearth of contemporary blood lead sampling programs.

Lead exposure from soils and dusts in Australian communities is dominated by three sources: (i) mining and smelting emissions, (ii) lead paint and (iii) leaded petrol. In mining and smelting affected areas, the original contaminant load is sourced primarily from smelter fallout, dust from spoil heaps or tailings that have been transported deliberately or inadvertently into and dispersed across human and natural environments. The release of such contaminants can pose a significant potential environmental and human health threat to people living and working in or near such environments. Lead levels in domestic paint were up to $50 \%$ by weight before the 1950 s but thereafter several reductions were mandated bringing the allowable concentration to $0.1 \%$ in 1997 (Australian Government Department of the Environment, 2013a). Nevertheless, the legacy of paint continues to pose a significant source of lead exposure in Australia (Gulson et al., 2006), though exposures are often a complex mix of sources (Gulson et al., 2013; Laidlaw et al., 2014a).

Unleaded petrol for road vehicles was introduced in Australia in 1985, with the lead content of petrol declining from $0.84 \mathrm{~g} / \mathrm{L}$ in 1990 to $0.2 \mathrm{~g} / \mathrm{L}$ in 1996 , until it was finally banned in 2002 (Australian Government Department of the Environment, 2013b). The consequences of the use of lead in petrol on environmental quality have been significant. In two national assessments of petrol lead emissions 3842 tonnes of lead were emitted in Australian capital cities in 1976 (Farrington, 1981), and 2388 tonnes of lead were emitted in 1985 (Farrington, 1988), despite the mandated reductions of allowable lead in petrol. As a result, soil in gardens and parks in many of the older, inner city areas of Australia became heavily contaminated with lead (Davis and Birch, 2011; Davis et al., 2011; Laidlaw and Taylor, 2011; Laidlaw et al., 2014a) and it is these sources that continue to expose children to potentially adverse levels of environmental lead. In contrast, smaller rural towns with lower vehicle use and population densities, and no mining and smelting industries are likely to have a less significant legacy of environmental lead exposure compared to major lead mining and smelting cities (Taylor et al., 2010). Exceptions in these locations include older housing where lead paint was used or where the source of drinking water is rainwater, river water or groundwater which has not been tested for lead (Green, 2013).

Although Australia continues to be a world leader in lead metal mining, smelting and processing, there has been a significant lack of research funding directed towards understanding the hazards of these operations. For example, there has never been any major longitudinal study investigating environmental lead plus other metal exposures in Mount Isa or Broken Hill, despite their importance in the Australian landscape and the current and historic childhood (and occupational) lead exposures (Taylor et al., 2011). Despite the fact that leadimpacted mining and smelting communities, councils, mining companies and government have often worked together to reduce exposures, any negative human health impacts arising from lead extraction and refining has been down-played consistently so as to not challenge the status quo and disrupt economic opportunities (Gulson, 2008; Laidlaw et al., 2014b; Lanphear et al., 2008; Taylor, 2012; Taylor and Schniering, 2010). Taylor et al. (2014) detail significant evidence of government agency obfuscation of the magnitude and human health risks associated with atmospheric emissions of lead as well as arsenic, cadmium and sulfur dioxide from the operations at Mount Isa and Port Pirie.

Atmospheric lead emissions from current mining and/or smelting operations continue to pose a major source of exposure at Broken Hill, Port Pirie and Mount Isa, with 28 tonnes; 46 tonnes and 120 tonnes being emitted to the respective ambient environments in 2011/12 (National Pollutant Inventory, 2014). Scrutiny of annual blood lead statistics from Port Pirie and Broken Hill show that childhood blood lead exposures in these towns are elevated and by some measures increasing by comparison to the national and global trend of falling levels. In Broken Hill the geometric mean blood lead of children aged 1-4 years rose from $4.8 \mu \mathrm{g} / \mathrm{dL}$ in 2011 to $5.4 \mu \mathrm{g} / \mathrm{dL}$ in 2012 , with the proportion of children over the national goal of $10 \mu \mathrm{g} / \mathrm{dL}$ increasing from 2010 to 2013: $12.6 \%$ to $13 \%$ to $21 \%$ (age-sex standardized values) (Lesjak et al., 2013). In Port Pirie, a similar pattern is emerging with the percentage of children younger than 5 years of age with a blood lead $>10 \mu \mathrm{g} / \mathrm{dL}$ remaining above $20 \%$. In $2011,24.2 \%$ of children younger than 5 years of age (excluding maternal blood lead as surrogate values) had blood lead values above $10 \mu \mathrm{g} / \mathrm{dL}$. In 2012 the proportion of Port Pirie children above the Australian national goal was similar to 2011 at $24.9 \%$ and slightly lower in 2013 at 22.7\% (Simon and Lewis, 2014). The geometric mean of children aged 24 months, continues to remain elevated; $6.1 \mu \mathrm{g} / \mathrm{dL}$ in 2011, $6.2 \mu \mathrm{g} / \mathrm{dL}$ in 2012 and $6.0 \mu \mathrm{g} / \mathrm{dL}$ in 2013 (Simon and Lewis, 2014). The geometric mean blood lead value for all children under 5 years of age rose in the last reporting year from $4.5 \mu \mathrm{g} / \mathrm{dL}$ to $5.0 \mu \mathrm{g} / \mathrm{dL}$, indicating strongly that the problem of exposure at Port Pirie persists.

Similarly detailed annual analysis is not available for Mount Isa despite the fact that in 2008 a survey of 400 children aged 1-5 years revealed that $11.3 \%$ had a blood lead level above $10 \mu \mathrm{g} / \mathrm{dL}$ (geometric mean $5 \mu \mathrm{g} / \mathrm{dL}$; Queensland Health, 2008). A smaller survey in 2010 ( $n=167$ children) showed that the number of children impacted was lower with $4.8 \%$ having a blood lead level above $10 \mu \mathrm{g} / \mathrm{dL}$ (geometric mean $4.27 \mu \mathrm{g} / \mathrm{dL}$; Queensland Health, 2010). From March 2014, Queensland Health Authority has resolved to undertake routine screening for lead when other blood tests are ordered for children aged $0-4$ years at Mount Isa Hospital. The objective of the new program is to obtain a more accurate assessment of blood lead, particularly in high risk groups such as indigenous children and those from lower socio-economic groups (North Queensland Register, 2014).

\section{Conclusions}

The lead pandemic is not a problem of the past. Further efforts to remain vigilant from both governance and community perspectives are urgently required, particularly in light of the evidence for the effects at much lower levels than the current Australian goal for blood lead. This vigilance needs to be supported by adequate state and national 
government funding given that environmental lead exposures are a matter of public health and its damaging effects are borne ultimately by the whole community. There is now an overwhelming body of evidence showing that Australia's lead level for children is too high. Therefore, in conclusion, we ask why would it take the NHMRC so long (2012-2014) to undertake what appears to be a review of reviews (NHMRC, 2014), in the anticipation that they might conclude something different from other global experts? Procrastination on this issue will be the thief of an equitable and healthy start to life for Australia's lead-exposed children.

\section{References}

Australian Bureau of Statistics (ABS). 3235.0 - population by age and sex, regions of Australia, 2012. http://www.abs.gov.au/ausstats/abs@nsf/Products/3235.0 2012 Main+Features Main+Features?OpenDocument\#PARALINK6, 2013. [accessed March 28th 2014].

Australian Government ComLaw. Australian Institute of Health and Welfare Act 1987. http://www.comlaw.gov.au/Details/C2012C00033/Download, 2014. [accessed March 28th 2014].

Australian Government Department of the Environment. Lead alert facts: lead in house paint. Canberra, ACT: Australian Department of Environment; 2013a [http://www. environment.gov.au/resource/lead-alert-facts-lead-house-paint (accessed March 28th 2014)].

Australian Government Department of the Environment. National phase out of leaded petrol. Canberra, ACT: Australian Department of Environment; 2013b [http://www. environment.gov.au/resource/national-phase-out-leaded-petrol (accessed March 28th 2014)]

Australian Institute of Health \& Welfare (AIHW)http://www.aihw.gov.au/about/, 2014 [accessed March 28th 2014].

Canadian Environmental Health Atlashttp://www.ehatlas.ca/lead/human-impact/healthconcerns, 2014. [accessed March 28th 2014].

Centre for Disease Control and Prevention (CDC). CDC response to Advisory Committee on Childhood Lead Poisoning Prevention recommendation in 'low level lead exposure harms children: a renewed call for primary prevention. Atlanta: US Centers for Diseases and Prevention; 2012 [http://www.cdc.gov/nceh/lead/ACCLPP/CDC Response_Lead_Exposure_Recs.pdf (accessed March 28th 2014)].

Davis BS, Birch GF. Spatial distribution of bulk atmospheric deposition of heavy metals in metropolitan Sydney, Australia. Water Air Soil Pollut 2011;214:147-62.

Davis BS, Vanderhayden M, Olmos M. The nature and distribution of metals in soils of the Sydney estuary catchment, Australia. Water Air Soil Pollut 2011;216:581-601.

Donovan J. Lead in Australian children. Report on the national survey of lead in children. Canberra: Australian Institute of Health and Welfare; 1996. p. 124. [http://www.abc. net.au/radionational/linkableblob/3988162/data/lead-in-children-data.pdf (accessed March 28th 2014)].

Earl R. An investigation of the effects of lead on children's cognitive abilities [PhD thesis] Adelaide: University of Adelaide; 2011 [http://digital.library.adelaide.edu.au/dspace/ bitstream/2440/71322/1/02whole.pdf (accessed March 28th 2014)].

Farrington V. Air emissions inventory (1976) for the Australian capital cities. Canberra: AGPS; 1981 [http://catalogue.nla.gov.au/Record/2270078 (accessed March 28th 2014)].

Farrington V. Air emissions inventory (1985) for the Australian capital cities. Canberra: AGPS; 1988 [http://catalogue.nla.gov.au/Record/1973311 (accessed March 28th 2014)].

Flegal AR, Smith DR. Lead levels in preindustrial humans. N Engl J Med 1992;326:1293-4.

Food and Agriculture Organization (FAO) of the United Nations and World Health Organization (WHO). Summary report of the seventy-third meeting of JECFA. Geneva, Switzerland: Joint FAO/WHO Expert Committee on Food Additives; 2010 [http:// www.who.int/foodsafety/publications/chem/summary73.pdf (accessed 14.01.14)].

Green J. Don't drink the water. Background briefing. Sydney: ABC; 2013 [http://www.abc. net.au/radionational/programs/backgroundbriefing/2013-03-31/4594752 (accessed March 28th 2014)].

Gulson BL. Can some of the detrimental neurodevelopmental effects attributed to lead be due to pesticides? Sci Total Environ 2008:396:193-5.

Gulson B. Comments on: identification of lead sources in residential environments: Sydney Australia. By Laidlaw, M.A.S., Zahran, S., Pingitore, N., Clague, J., Devlin, G., Taylor, M.P., 2013. Environ Pollut 2014;184:238-46. [Environmental Pollution, 185, 372-373].

Gulson G, Mizon K, Taylor A, Korsch M, Stauber J, Davis JM, et al. Changes in manganese and lead in the environment and young children associated with the introduction of methylcyclopentadienyl manganese tricarbonyl in gasoline-preliminary results. Environ Res 2006;100(1):100-14

Gulson B, Mizon K, Taylor A, Korsch M, Stauber J, Davis JM, et al. Longitudinal monitoring of selected elements in blood of healthy young children. J Trace Elem Med Biol 2008; 22:206-14.

Gulson G, Anderson P, Taylor A. Surface dust wipes are the best predictors of blood leads in young children with elevated blood lead levels. Environ Res 2013;126:171-8.

Health Canada. Final health state of the science report on lead. Ottawa, Ontario, Canada: Health Canada; 2013 [http://hc-sc.gc.ca/ewh-semt/pubs/contaminants/dhhssrlrpecscepsh/index-eng.php (accessed March 28th 2014)].

Laidlaw MAS, Taylor MP. Potential for childhood lead poisoning inner cities of Australia due to exposure to lead in soil dust. Environ Pollut 2011;159:1-9.
Laidlaw MAS, Zahran S, Pingitore N, Clague J, Devlin G, Taylor MP. Identification of lead sources in residential environments, Sydney Australia. Environ Pollut 2014a;184: 238-46.

Laidlaw MAS, Zahran S, Pingatore N, Clague J, Devlin G, Taylor MP. Reply to comments on "Identification of lead sources in residential environments: Sydney Australia" by Laidlaw et al. (2014). Environ Pollut 2014b. http://dx.doi.org/10.1016/j.envpol.2013. 10.020 .

Lanphear BP, Hornung R, Khoury J, Yolton K, Baghurst P, Bellinger DC, et al. Low-level environmental lead exposure and children's intellectual function: an international pooled analysis. Environ Health Perspect 2005;113:894-9.

Lanphear BP, Hornung RW, Khoury J, Dietrich KN, Cory-Slechta DA, Canfield RL. The conundrum of unmeasured confounding: "can some of the detrimental neurodevelopmental effects attributed to lead be due to pesticides? by Brian Gulson". Sci Total Environ 2008;396(2-3):196-200.

Lesjak M. Blood lead trends in children aged less than 5 years in Broken Hill 2011. Broken Hill Public Health Unit Far West Local Health District, New South Wales Health, New South Wales Government; 2012 [http://www.fwlhn.health.nsw.gov.au/UserFiles files/FAR\%20WEST\%20Lead\%20Health\%20Data\%20Report\%202011.pdf (accessed March 28th 2014)].

Lesjak M, Gough N, Belshaw D, Tall J, Jones T. Lead health report - children less than 5 years old in Broken Hill. Population Health Unit, Western NSW \& Far West Loca Health District. New South Wales Health, New South Wales Government; 2013 [http://www.wnswlhd.health.nsw.gov.au/UserFiles/files/FarWest/ANNUAL\% 20LEAD\%20REPORT\%202012\%20Final.pdf (accessed March 28th 2014)]

Living with Lead. Living safely with lead. Queensland Government, Mount Isa Mines and Mount Isa City Council; 2013 [http://www.livingwithlead.com.au/about-lead (accessed March 28th 2014)].

Medicare Australia Statistics. Medicare item 66665 (lead quantification in blood or urine) July 2003-August 2013. https://www.medicareaustralia.gov.au/cgi-bin/broker.exe? PROGRAM =sas.mbs_item_standard_report.sas\&_SERVICE $=$ default\&DRILL $=$ ag\& $\mathrm{DEBUG}=0 \&$ group $=66665 \& \mathrm{VAR}=$ services $\& S T A T=$ count $\&$ RPT_FMT $=$ by + state $\&$ PTYPE $=$ finyear\&START_DT $=200307 \& E N D \_D T=201308$, 2014. [accessed March 28th 2014].

Menke A, Muntner P, Batuman V, Silbergeld EK, Guallar E. Blood lead below $0.48 \mu \mathrm{mol} / \mathrm{L}$ $(10 \mu \mathrm{g} / \mathrm{dL})$ and mortality among US adults. Circulation 2006;114(13):1388-94.

Mielke HW, Zahran S. The urban rise and fall of air lead ( $\mathrm{Pb})$ and the latent surge and retreat of societal violence. Environ Int 2012;43:48-55

National Health and Medical Research Council (NHMRC). Information paper - blood levels for Australians. Canberra: National Health and Medical Research Council; 2009 [http://www.nhmrc.gov.au/_files_nhmrc/publications/attachments/gp2-leadinfo-paper.pdf (accessed March 28th 2014)]

National Health and Medical Research Council (NHMRC). Blood lead levels for Australians. Canberra: National Health and Medical Research Council; 2014 [http:// www.nhmrc.gov.au/guidelines/publications/eh55 (accessed March 28th 2014)]

National Pollutant Inventory. National pollutant inventory. Australian Government, Department of Sustainability, Environment, Water, Population and Communities; 2014 [http://www.npi.gov.au (accessed March 28th 2014)]

North Queensland Register. Mt Isa lead levels screening. http://www northqueenslandregister.com.au/news/agriculture/general/news/mt-isa-lead-levelsscreening/2687175.aspx, 2014. [accessed March 28th 2014].

Queensland Health. Mount Isa community lead screening program 2006-7. A Report into the results of a blood-lead screening program of 1-4 year old children in Mount Isa, Queensland. Townsville: Environmental Health Services of the Tropical Population Health Network, Northern Area Health Service. Queensland Health; 2008 [http:/ www.health.qld.gov.au/ph/documents/tphn/mtisa_leadrpt.pdf (accessed March 28th 2014)]

Queensland Health. Mount Isa community lead screening program 2010. A report into the results of a blood-lead screening program of 1-4 year old children in Mount Isa, Queensland. Tropical Regional Services, Division of the Chief Health Officer, Queensland Health; 2010 [http://www.health.qld.gov.au/ph/documents/tphn/lead_report 2010.pdf (accessed March 28th 2014)].

Schober SE, Mirel LB, Graubard BI, Brody DJ, Flegal KM. Blood lead levels and death from all causes, cardiovascular disease, and cancer: results from the NHANES III mortality study. Environ Health Perspect 2006;114(10):1538-41.

Schultz C, Wilhelm M, Heudorf U, Kolossa-Gehring M. Update of the reference and HBM values derived by the German Biomonitoring Commission. Int J Hyg Int Health 2011; 215:26-35.

Simon S, Lewis C. Analysis of blood lead levels for 2013 (1 January 2013-31 December 2013). Technical paper 2013/4. South Australia Health, Government of South Australia; 2014. p. 7 [http://www.sahealth.sa.gov.au/wps/wcm/connect/ 8713ab80430ab0b1b275b29d0fd82883/TECHNICAL+PAPER+No+2013 4+ analysis + of + blood + lead + levels + for $+2013+\% 281+$ January $+2013+-+31+$ December $+2013 \% 29$.pdf?MOD = AJPERES\&CACHEID = 8713ab80430ab0b1 b2 75b29d0fd82883 (accessed March 28th 2014)].

Taylor MP. Lead poisoning of Port Pirie children: a long history of looking the other way. The conversation; 2012 [http://theconversation.edu.au/lead-poisoning-of-port-piriechildren-a-long-history-of-looking-the-other-way-8296, (accessed March 28th 2014)]

Taylor MP, Schniering CA. The public minimization of the risks associated with environmental lead exposure and elevated blood lead levels in children, Mount Isa, Queensland, Australia. Arch Environ Occup Health 2010;65:45-8.

Taylor MP, Hudson-Edwards KA, Mackay AK, Holz E. Soil Cd, Cu, Pb and Zn contaminants around Mount Isa City, Queensland, Australia: potential sources and risks to human health. Appl Geochem 2010;25(6):841-55

Taylor MP, Schniering CA, Lanphear BP, Jones AL. Lessons learned on lead poisoning in children: one-hundred years on from Turner's declaration. J Pediatr Child 2011;47: 849-56. 
Taylor MP, Winder C, Lanphear BP. Eliminating childhood lead toxicity in Australia: a call to lower the intervention level. Med J Aust 2012;197(9):493.

Taylor MP, Davies PJ, Csavina J, Kristensen LJ. Licenced to pollute but not to poison: the ineffectiveness of regulatory authorities at protecting public health from atmospheric arsenic, lead and other contaminants resulting from mining and smelting operations. Aeolian Res 2014. http://dx.doi.org/10.1016/j.aeolia.2014.03.003.

Thumbs Up for Low Levels. Aims. CANdO Committee; 2013 [funded by Nyrstar Port Pirie http://thumbsupforlowlevels.com/about-us/aims (accessed March 28th 2014)]

United States Environmental Protection Agency (US EPA). US EPA integrated science assessment for lead (final report). U.S.A. EPA/600/R-10/075F. Washington, DC:
Environmental Protection Agency; 2013 [http://cfpub.epa.gov/ncea/cfm/ recordisplay.cfm?deid=255721 (accessed March 28th 2014)].

United States National Toxicology Program (US NTP). NTP monograph on health effects of low-level lead. North Carolina: US National Toxicology Program, Research Triangle Park; 2012 [http://ntp.niehs.nih.gov/go/36443(accessed March 28th 2014)].

World Health Organisation (WHO). Childhood lead poisoning. Geneva: World Health Organisation; 2010 [http://www.who.int/ceh/publications/leadguidance.pdf (accessed March 28th 2014)]. 